\title{
Global Crop Value Chains: Shifts and Challenges in South-North Relations
}

\author{
Stefan Nier, Oliver Klein * and Christine Tamásy \\ Institute for Geography and Geology, Human Geography, University of Greifswald, \\ Friedrich-Ludwig-Jahn-Strasse 17a, 17487 Greifswald, Germany; \\ stefan.nier@uni-greifswald.de (S.N.); christine.tamasy@uni-greifswald.de (C.T.) \\ * Correspondence: oliver.klein@uni-greifswald.de; Tel.: +49-3834-420-4530
}

Received: 30 November 2018; Accepted: 28 February 2019; Published: 7 March 2019

\begin{abstract}
The worldwide importance of crop production is undisputed due to its function for basic nutrition of billions of people. Yet, the emergence of global forces implies severe consequences for the organization of crop value chains. These forces particularly include processes of liberalization and deregulation, the dominance of large retail groups as well as ever-changing consumer demands, leading to continuous reconfigurations of crop value chains. Based on a literature review, this paper aims at thematically 'organizing' and differentiating the key findings of relevant empirical studies on global crop value chains, with a particular focus on South-North relations. Thereby, current shifts and challenges are identified and analysed with special attention paid to spatio-relational dimensions. The spatial perspective is important since crop value chains both shape and are shaped by specific geographical settings which is, among others, considered in the growing literature on food geographies. Overall, we could extract three strands of literature on global crop value chains: the integration of smallholders; the role of food standards; and the effect of 'hidden' dynamics. These issues especially reveal the interdependencies between the Global South and the Global North as a crucial feature of contemporary crop production and distribution systems. These are A further outcome of the literature analysis is the derivation of suggestions regarding future research and areas of needed progress.
\end{abstract}

Keywords: value chains; crop production; globalization; food geographies; developing countries

\section{Introduction}

The growing integration of worldwide agrifood markets has resulted in the emergence of new or revised configurations of food value chains, often linking large buyers from the Global North ${ }^{1}$ with small primary producers from the Global South ${ }^{2}$. This situation is especially true for the production and distribution of crop plants ${ }^{3}$, as described by several authors (e.g., Gijsbers 2009; Humphrey 2006a; Jaenicke and Virchow 2013; Ruel et al. 2014). A key role is attributed to large retailing groups whose global sourcing strategies seek to build, reinforce or erode supply relations with crop producers from developing and emerging countries. From a developmental viewpoint, the integration (or exclusion)

1 In this paper, the term 'Global North' refers to the 'industrialized world,' including North America, Europe (including Russia), East Asia (i.e., Japan, South Korea) as well as Australia and New Zealand (though acknowledging that the latter two countries are located in the Southern hemisphere).

2 Accordingly, the term 'Global South' refers to the 'emerging' and 'developing world,' including all countries/regions that have not been mentioned under 'Global North.'

3 We basically refer to all crop plants that are used for human nutrition. These mainly include cereals, vegetables, fruits, sugar crops, root/tuber crops and oilseed crops (according to Food and Agriculture Organization of the United Nations FAO). 
of smallholders into (or from) these far-reaching crop value chains is an important question in terms of rural livelihood improvement in developing countries (e.g., Humphrey 2008; Riisgaard et al. 2010; Seville et al. 2011). This is only one example for the various challenges which may contribute to shifting South-North relations in the global crop sector. Further challenges may refer to the impact of climate change, the implementation of institutional arrangements or the rising demands on food quality as stipulated by standards. All these issues are important driving forces behind the adaptation and reorientation of crop production and distribution practices both in the Global North and the Global South, while, simultaneously, contributing to the emergence of 'new geographies' in crop value chains.

Against this background, the aim of this paper is to provide an overview of current challenges in the global crop sector (as indicated above) and to analyse their impact on the organization of South-North relations. Thereby, the spatial perspective gains particular importance since food value chains both shape and are shaped by specific geographical settings which is, among others, considered in the growing literature on food geographies (e.g., Goodman 2016; Goodman et al. 2010; Morgan et al. 2006; Niles and Roff 2008; Stringer and Heron 2008; Winter 2003, 2004, 2005). Addressing crop plants as still the most important but also most vulnerable nutritional foodstuff worldwide (Food and Agriculture Organization of the United Nations FAO), our intended contribution is to synthesize the existing literature on this specific field as a means of thematically 'organizing' and differentiating the key findings of relevant empirical studies. We do so by conducting an analysis of recent literature on crop value chains, while especially studying various challenges that become evident in South-North relations, which are mainly driven by large retailers from Europe and the United States. This effort follows the tradition of recent literature reviews on food value chains undertaken by, among others, (Bonnano et al. 2018); (Ponte 2016) and (Schumacher 2014). We wish to add that such an approach does not claim a comprehensive and all-encompassing synopsis but rather strives for a (selective) cross section of issues that influence the changing nature of global crop value chains in both socio-economic and spatio-relational terms. As an outcome of this literature analysis, we seek to formulate some suggestions concerning future research and areas of needed progress.

The literature analysis is focused on Anglophone publications ${ }^{4}$ on crop value chains that have been found using the web-search engine Google Scholar, indexing full-text scholarly literature across many disciplines and databases. The literature includes journal and conference papers, theses and dissertations, academic books, pre-prints, abstracts, technical reports and other scholarly publications. When searching a topic in Google Scholar, a list of publications is created, which can be filtered by either 'most relevant papers first' or 'most recent papers first'. Thereby, researchers may also identify more articles on a given topic by reviewing citations of those articles ('snowball' sampling), providing researchers "a broad overview of the direction of research about this topic through an easy, real time citation finder" (Zientek et al. 2018, p. 41). We started the selection of literature by searching and filtering the keywords 'crop(s)' and 'value chain(s),' resulting in a previous sample of 280 papers ${ }^{5}$ (until 30 June 2018), which, though being thematically very diverse, provide a comprehensive overview on our field of research. Through further refinement of the literature search by adding the term 'globalization,' we could extract 73 relevant publications as the preliminary basis of the literature review. This procedure was supplemented by 'snowball' sampling, that is, the exploration of articles most cited in the screened literature. ${ }^{6}$ After the identification of the articles, we analysed their abstracts according to the treated topics, which then were grouped into different preliminary categories (i.e., smallholder production, trade relations, standards). In a second step, these categories were assembled

4 We focus on Anglophone literature, since the dissemination of scientific knowledge is fundamentally done in English; thus, it is a criterion used in various reviews (López-Fernández et al. 2016).

5 The current importance of crop value chains in science and research is shown by a strong increase of relevant publications per year, particularly after 2011 (according to Google Scholar).

6 The papers were mostly published in transdisciplinary journals such as Food Security, Food Policy, Global Food Security, Journal of Rural Studies, Food Research International or Agriculture and Human Values. 
into overarching thematic clusters, framing and constituting South-North relations in global crop value chains as the main direction of this review. This step also includes the rejection of singular papers that did not fit with the identified clusters. The following detailed exploration of the articles was based on a content analysis following (Mayring 2014) and his content-analytical method of structuring. This method draws upon a more sophisticated classification of the literature material, providing the basis for interpretation and further development of (sub-)topics.

The structure of this paper is organized as follows: After the introduction, we continue by outlining the contextual background relating to global food value chains in general. This is followed by the results derived from the literature analysis, exploring shifts and challenges in global crop value chains in more detail. This section is organized into three key areas that we found to have various potentials to transform South-North relations in the global crop sector. We finally conclude by a brief summary and an outlook for future research.

\section{Background}

In the course of increasing world market integration due to deregulation and liberalization, the organization and coordination of global food value chains have changed significantly: "At present, food may come ready-to-eat (through microwave or steam oven) and organic, can be bought in processed and packed form in the supermarket or obtained unprocessed and raw from the farm or the farmers' market. ( ... ). Food factories may transform locally produced potatoes into countless varieties of crisps and add their carbon footprint on the package when shipping them to foreign destinations, whereas organic retail chains distinguish themselves by purchasing as much as possible from local farmers" (Spaargaren et al. 2012, p. 1). This diverse and contrasting picture is the result of a long-running process of constant change in food production predominantly based on principles of rationalization and standardization as well as on niche developments.

Before exploring these developments in more detail, it is first useful to describe the structures, functions and actors typically defining the configuration of food value chains. A value chain, in general, involves "the processes and actors that take a product from its conception to its end use or disposal. (... ) value is added to the product through 'value-adding' activities as it passes through the chain" (Hawkes and Ruel 2012, p. 74). The specific structure of a food value chain consists of various types of input suppliers, primary producers, further and/or final manufacturers, distributors, wholesale and/or retail traders and, finally, consumers. Here, it is important to note that these types of actors not only follow each other in a linear manner but are mutually linked through material and immaterial flows of commodities, capital, labour, information, knowledge and power (e.g., Alkon and Guthman 2017; Morgan et al. 2006; Stringer and Heron 2008). The formation and functional integration of the value chain actors constitute a variety of spatio-relational configurations that are shaped by interactions across multiple scales. These interactions are primarily driven by market forces and regulated by a huge number of rules, norms and institutions, together defining food value chains as systemic entities (e.g., Hughes et al. 2013; Pritchard et al. 2016; Thomsen 2016). Thus, agrifood scholars today increasingly prefer the terms 'food system' or 'food network' rather than the 'chain' metaphor, while simultaneously emphasizing the intersection of industrial conventions of mass production, global distribution pathways, free trade and regulatory harmonization with food safety and quality issues as well as environmental and social justice sensibilities (Niles and Roff 2008).

Along with the industrialization and modernization of the agrifood sector, the structures and functions of food value chains have grown in complexity, becoming manifest in the introduction of factory-style farming, including the mechanization and automation of production processes in agriculture, the increasing dependence on contract farming, the transformation of labour and management structures, in which individual farms and regions specialize in particular products, or, in other words, the expansion of the agribusiness model of production (Tamásy 2013). As a result, new products, capabilities and networks have emerged, linking different actors around the world and increasingly defining what (Fraser 2016) refers to as 'global foodscapes.' It is important to see these 
trends in the context of neo-liberal markets and the concentration in corporate control of the agrifood sector. While firms such as Coca-Cola, Nestlé, Kraft Foods or Unilever create global brand names and rely on transnational forms of market integration, they simultaneously attempt "to appropriate some of the functions of agriculture in ways that stretch links, networks and chains between production and consumption spheres" (Morgan et al. 2006, p. 53). Another major trend in the contemporary agrifood system includes the spectacular rise of corporate retail, with a clear power shift implicating buyer driven processes of value creation (e.g., Bek et al. 2016; Fold and Larsen 2011; Hughes et al. 2013).

During the second half of the 20th century, the pace and intensity of these developments clearly increased and the concentration of production and distribution functions became one of the most striking phenomena affecting food value chains in both industrial and developing countries (Howard 2016). Thereby, concentration has proceeded most rapidly in the downstream areas of the food value chain, that is, in the food retailing sector which is dominated by always fewer international corporate groups (e.g., Barrientos and Dolan 2006; Brown 2005; Dobson et al. 2003; Gereffi and Christian 2010). Today, the configuration of food value chains depends to a great extent on the requirements of large retailers, such as Walmart, Tesco or Aholt, which may demand large-volume supply, speed and reliability of delivery, customization of products through processing and packaging as well as guarantees about product safety (e.g., Bolwig et al. 2013; Humphrey 2006a; Humphrey and Memedovic 2006). This way of exerting power is usually referred to as 'value chain governance'. The mode of governance, however, is not only related to the power (and powerlessness) of firms but also to the institutional framework, defined as 'the rules of the game' in national and international contexts: "It is not so much the spatiality of the chains as such that adds to our understanding of intrachain relations but rather the nature of the territories with all their contextually shaped and influenced functions, including regulation, infrastructure, political economy, labour relations and so on, that are essential" (Thomsen 2016, p. 835).

Finally, food value chains are shaped by the ever-changing consumer demands in both the Global North and the Global South. While dietary habits are affected by various influential factors (e.g., age, income, mobility, household structure, cultural traditions, lifestyle), food suppliers seek to provide a wide range of diverse foodstuff in order to meet these differentiations in the demand structure (e.g., Fold and Gough 2008; Monteiro et al. 2013; Schröder 2003). Currently, there is a trend towards high processed food ('ready-to-eat' or 'ready-to-cook') due, among others, to the lack of time for every day cooking, especially in the industrialized world ('products for cash-rich but time-poor consumers'). But also in the emerging markets (e.g., Brazil, China, India), there is a significant change of consumer behaviours, with 'Western foods' influencing the dietary cultures to an ever greater extent, particularly in the metropolitan areas of these countries. This homogenization of food culture is indicated, for example, by the quick expansion of fast food chains (e.g., McDonald's, Burger King, Subway).

In sum, food value chains are subject to multiple challenges particularly brought about by the forces of globalization. Facing these challenges may result in a far-reaching restructuring of food value chains in both organizational and geographical terms. In the following sections, we aim to shed light on these issues by the example of the global crop sector with a particular focus on shifts and challenges affecting the respective value chains, with a special focus on South-North relations.

\section{Results}

When analysing crop value chains, many authors are concerned with aspects of poverty alleviation, smallholder production and food safety as the three most investigated issues derived from our literature sample. More precisely, such mainly development-oriented studies deal, among others, with forms of subsistence farming (e.g., Baiphethi and Jacobs 2009), strategies for improving productivity of small-scale agriculture (e.g., Ruel et al. 2014) or impacts of quality standards set by large food retailers from the Global North (e.g., Seville et al. 2011). With regard to the industrialized world, crop value chain studies are, in general, more technological-oriented with a strong focus on research and development 
(R\&D) activities, especially in terms of food safety (e.g., Schröder 2003; Shukla and Jharkharia 2013), healthy nutrition (e.g., Miller and Welch 2013) or food waste management (e.g., Gooch et al. 2010). Thus, research activities on crop production in developed countries clearly reflect the 'typical' food concerns of an affluent society, whereas respective studies in developing countries tend to reproduce 'the daily struggle to survive' of peasant farmers and the overall population. Regardless of the geographical focus, however, crop value chains are principally based on a complex set of spatial relations ranging from the local to the global scale. Taking this into account, the following considerations aim to reveal a range of shifts and challenges that may affect the configuration of global crop value chains and their inherent (and latent) spatialities.

\subsection{Integrating Smallholders into Global Crop Value Chains-A Strategy for Poverty Alleviation and Rural Development?}

The economic importance of crop production especially in rural areas has been adequately described in the literature (e.g., Baiphethi and Jacobs 2009; Humphrey 2006b; Jayne et al. 2010; Riisgaard et al. 2008). In developing countries, the crop sector often provides the only source of nutrition, income and employment for rural populations who otherwise have very limited access to markets, capital, technologies and information. These populations strongly depend on smallholder production and subsistence farming, while permanently being threatened by food insecurity and poverty. The reduction of poverty is therefore directly linked to agriculture in general and crop production in particular (e.g., Jack 2013; Seville et al. 2011). Studies have also shown that growth generated by agriculture is up to four times more effective in reducing poverty than the growth in other sectors (Båge 2008). One possible strategy to improve rural livelihoods in the Global South aims at integrating smallholders into global crop value chains as a vehicle for economic upgrading. However, the literature reviewed is rather inconsistent when evaluating the development outcomes in this respect.

A first strand of literature generally relates to the potentials and constraints for smallholders to benefit from participation in crop value chains that are driven by large food retailers from the Global North. Over the past three decades, these retailers have expanded into ever more countries of the Global South through liberalization processes and new information, communication and logistics technologies (Gijsbers 2009; Reardon and Timmer 2012; Reardon et al. 2003; see also the 'waves model' by Reardon et al. 2007). As a result, food markets in many countries of Africa, Asia and Latin America have changed significantly, posing new challenges for small farmers and crop producers. However, these developments also offer several opportunities for the peasant sector. According to Reardon and colleagues, for example, the emergence of major food retailers in Latin America has led to the building of intense trade relations with local fruit and vegetable producers, resulting in long-term and reliable income opportunities for them (Reardon and Berdegué 2002; Reardon et al. 2003). Further opportunities for smallholders to enhance their livelihoods are linked to the increasing demand for high-value food products, as argued, among others, by (Gaiha and Thapa 2008). Focusing on selected Asian countries, the authors show that smallholders gain several comparative advantages (over large commercial farmers), enabling them to easily integrate into the emerging supply chains. For example, the traditional farming practices of vegetable growers in rural Thailand prove to be more amenable to the requirements of supermarkets, particularly in terms of organic production. However, small-scale farmers "typically have few assets to withstand the effects of risks and at the same time have little influence over key risk factors such as price cuts, cancellation of orders, moral hazard problems among buyers (cheating), new food safety legislation and new and more demanding quality standards" (Riisgaard et al. 2008, p. 17). This argument is supported by (Schneider and Gugerty 2011) who see a number of limiting factors for smallholders to participate in the market economy (beyond subsistence). These particularly include deficits in technological adaptation, asset endowment and market access. At least, there seems to be "strong evidence for indirect poverty reduction through employment generation, rural non-farm multiplier effects and food prices effects; however contextual 
factors determine whether market forces resolve most favourably for the poor" (Schneider and Gugerty 2011, p. 69).

In light of the various constraints for smallholder integration into global value chains, a second strand of literature deals with forms of horizontal collaboration among rural crop producers in developing and emerging countries. In this context, (Trebbin 2014) analyses possible strategies for Indian smallholders (mostly crop producers) to enhance their position within the (buyer-driven) food value chain. She concludes that producer companies ${ }^{7}$ could be a promising element for becoming part of modern retailers' supply chains but that only relatively few have succeeded so far. A crucial reason behind this failure is a lack of targeted support for this new form of farmer organization. Therefore, the government should undertake greater efforts not only in financial terms but also in making information on producer companies easily available for all parties interested. In this regard, the author argues that "a mixed promoter consortium of NGOs, input suppliers and potential buyers might be a possible solution to ensure a balance of interest between welfare and business orientation of producer companies" (Trebbin 2014, p. 43). With regard to governmental support policies, the study by (Ito et al. 2012) reveals different insights. Using the example of a watermelon producer cooperative in rural Nanjing, China, it is argued that publicly funded extension services have only a modest effect on farm income, while the average treatment effect of the cooperative is robust and substantially large. Thereby, it is important to note that the cooperative deliberately excludes a number of small-scale farmers "with a view to economizing on incremental transaction costs incurred and sharing production and marketing risks with better-off famers" (Ito et al. 2012, p. 708). Thus, the coexistence of smallholder inclusion and exclusion, driven by the profit-orientation of the cooperative, leads to polarization tendencies within the community and poses serious challenges to pro-poor agricultural growth in rural Nanjing.

A third strand of literature claims that food security and rural development can be achieved most effectively by developing subsistence economy. (Seville et al. 2011) estimate that $40-50 \%$ of rural farmers in developing countries are merely subsistence-oriented and further 20-30\% have only occasional access to markets. While these smallholders often face food insecurity and malnutrition, they strongly rely on support services provided by development agencies or non-governmental organizations (NGOs). Against this backdrop, (Baiphethi and Jacobs 2009) argue for the need to significantly increase the productivity of subsistence farming in order to reduce such dependencies. Drawing on examples from Malawi, Zambia and Mozambique, the authors suggest encouraging smallholders to pursue sustainable intensification of production through the use of improved inputs (e.g., fertilizers, plant protection products), combined with the development of well-functioning input and output markets. The challenge is, however, to enable the farmers to purchase the required inputs and to use them correctly. Therefore, adequate training programs as well as financial support or, at least, improvements in the access to off-farm income are key to increase the productivity in crop production and thus to achieve higher levels of food security in rural areas. From this viewpoint, the participation of smallholders in food markets on a larger scale is of secondary importance.

The initial question of whether smallholder integration into global crop value chains is a promising strategy for poverty alleviation and rural development cannot be answered in general. As the examples have shown, it depends significantly on the institutional context and the capacity of small-scale farmers to adapt to changing market environments. Such issues are specifically emphasized by (Vorley et al. 2007) dealing with the question of how modernization and restructuring of food supply chains affect food production and distribution systems, while also presenting best-practice in involving small-scale producers in supermarket supply chains. The findings are drawn from eighteen countries

7 The concept of producer companies was introduced by the Indian government in 2002. Producer companies maintain unique elements of cooperatives, while the regulatory framework is similar to that of other company types. In contrast to cooperatives, only persons directly involved in primary production can become members of producer companies (Trebbin 2014). 
participating in the 'Regoverning Markets' programme (e.g., Bangladesh, Ecuador, Vietnam, Uganda). However, where crop producers have no chance to fulfil the requirements of large food retailers, it has to be discussed whether or not the development of subsistence farming proves as a more effective strategy. We conclude this debate by quoting (Gaiha and Thapa 2008, p. 257) who describe necessary conditions for a fruitful and fair collaboration in the contemporary crop market: "The threats to the expansion of the livelihoods of smallholders and other poor segments in rural areas (e.g., agricultural labourers) could be turned into opportunities through mutually beneficial partnerships between supermarkets and smallholders and a macropolicy framework that protects the economic interests of smallholders." In this regard, the design and diffusion of food standards set by public and private stakeholders is a crucial issue that we address now.

\subsection{Food Standards in Global Crop Value Chains_-Impact and Governance Dimensions}

In recent years, the implementation and diffusion of food standards have become one of the most significant features affecting the configuration of global crop value chains (see, for an overview, Swinnen 2007). Yet, this is not at all a new phenomenon, since international food trade was shaped by standards in the middle of the 19th century (Humphrey 2006b). The majority of public standards set by developed countries is concerned with food safety and quality. After several food scandals (e.g., Bovine Spongiform Encephalopathy (BSE), Enterohemorrhagic Escherichia coli (EHEC), dioxin, 'rotten meat') food producers and retailers have intensified their efforts to ensure high quality foods and to restore the damaged trust of consumers. These aspirations have led to a rapid rise of food standards over the last two decades, with the result that the cultivation and production of food has been controlled more tightly from the downstream end of the value chain. A prominent example is the European standard Global Good Agricultural Practices (GlobalGAP) as a quasi-obligatory precondition for supplying large food retailers in the EU. The GlobalGAP standard defines minimum requirements on hygiene and food safety, plant protection, traceability as well as environmental and labour protection. With regard to the crop sector, several authors have examined the impact of standards, such as GlobalGAP, on small-scale farmers in the Global South, whereby the empirical results are quite different. We could identify three main outcomes that are described below.

Firstly, a series of studies indicate that the high requirements of food standards often result in market exclusion of crop producers in the Global South (e.g., Brown 2005; Graffham et al. 2007; Humphrey 2008; Mithöfer et al. 2008). In the context of EurepGAP 8 proliferation, for example, (Graffham et al. 2007) estimated the exclusion rate of Kenyan fruit and vegetable growers formerly producing for the EU-market at 60\% between 2003 and 2006. Based on a sample of ten interviewed exporters, the authors could show that 5475 out of 9342 small-scale growers had been excluded from the respective value chains, with $54 \%$ of them having failed for reasons of cost, while the remaining $46 \%$ were dropped by their exporter who was seeking an efficient and manageable number of growers to get through EurepGAP. On the other hand, "sustainable EurepGAP compliance by small-scale growers was found to be related to the level of commitment and resources made by the export company," whereby only the two schemes operated by the largest exporters in Kenya were running sustainably (Graffham et al. 2007, p. 29). These findings are supplemented by (Humphrey 2008, p. 77) who concludes that "independent small farmer groups have little or no chance of meeting EurepGAP requirements and that the role of processors and exporters is crucial in creating and sustaining EurepGAP-compliant production systems." Therefore, development policy measures that aim to enhance smallholders' compliance with standards must find ways of working effectively with private sector firms and strengthening their capacity to develop well-organized outgrower schemes as a solid basis for meeting the demands of European and US food retailers. 
Secondly, the debate on food standards and their impact on smallholders has also led to different outcomes that go beyond the exclusion narrative. Here, a prominent contribution by (Dannenberg and Nduru 2013) has shown that Kenyan fruit and vegetable growers are in fact able to enter the buyer-driven crop value chain (based on the GlobalGAP standard), even without being formally certified. Based on surveys and interviews with relevant stakeholders (e.g., smallholders, traders, retailers, certifiers), the authors could identify different types of informal arrangements that ensure keeping non-certified farmers within the chain. The most common way of participation is the long-term integration of non-certified farmers into exporter schemes. In this way, the respective produce is simply sold under the GlobalGAP certificate issued for the contractor (a certified large exporting farm that controls a number of small-scale growers in a quality management system). Another informal arrangement refers to the limited reliability of brokers ${ }^{9}$ who often use questionable methods that include mixing certified and uncertified produce. Taking into account "the conflicting EU retail requirements of flexibility and highly challenging product and process obligations," it is quite plausible that both producers and traders in Kenya have a strong interest in keeping also the 'non-compliant' farmers integrated (Dannenberg and Nduru 2013, p. 53). In this regard, it is a favourable precondition that there are different types of supply routes including a great number of direct and indirect connections which make it severely complicated for certifiers to control all steps of the production process. In conclusion, the authors regard their results as "the first to show that the integration and standardization even of highly sophisticated consumer markets do not necessarily lead to a large exclusion of small-scale businesses of developing countries" (Ibid., p. 54).

Thirdly, we could identify a (rather small) strand of literature aiming at providing implications for small-scale farmers that are challenged by food standards. For example, (Humphrey 2006a) argues that it is worth considering whether a focus on smallholder exports to large buyers in the Global North should be complemented or replaced by alternative strategies. Given the complexity and expenditure of meeting the requirements of standards, he suggests shifting the efforts to the potentials of traditional domestic markets and/or niche products that are not sold through the large retailing groups. Both strategies require improving the efficiency of respective marketing channels involving close collaboration between producers and marketers. A more radical argumentation goes back to (McCulloch and Ota 2002) who found that waged employment on large horticulture farms is just as poverty-reducing as smallholder production. Therefore, a strategy of allowing small-scale farms to decline and focusing instead on improving labour standards for dependent farm workers might be also worthy of consideration.

Summing up, it can be noted that meeting the requirements of food standards is a tough challenge for small-scale crop producers. Hence, a considerable part of the literature reviewed has provoked a vibrant exclusion debate with respect to the global crop sector. Nevertheless, there are also indications that some of the smallholders have in fact been able to enter the value chain by means of informal arrangements, as shown by (Dannenberg and Nduru 2013). However, smallholders may require manifold support in order to achieve compliance with food standards. A differentiated debate on this topic was initiated by (Swinnen 2007), who has brought together both conceptual thoughts related with the global diffusion of food standards and an extensive amount of empirical evidence in this area. Thus, the authors in Swinnen's collection contribute to a comprehensive viewpoint on the impact of food standards, especially in developing, emerging and transition countries and with a special focus on the production circumstances for local producers respectively poor, often rural, households. Against this background, it should be examined if and how alternative marketing strategies, as suggested by (Humphrey 2006a), could provide more promising outcomes than the desperate endeavour to integrate small-scale crop producers into global food value chains.

9 Brokers are small regionally based middlemen and transporters that fulfil an intermediary function between farmers and exporters. 


\section{3. 'Hidden' Dynamics in Global Crop Value Chains-Detecting Multiscalar Relations and 'Unexpected' Outcomes}

The previous sections have shown that contemporary food systems are characterized by a multiscalar structure, in that almost each stage of particular value chains connects actors and countries on a global scale. These linkages are mainly driven by the practices of global lead firms, operating transnational subsidiaries across the world, while simultaneously buying crops from small- and medium-sized farms in local economies (Gereffi and Christian 2010). The interaction between global and local fields of action may be direct but is often captured through indirect effects. While following food products from 'farm to fork,' several authors seek to uncover the 'hidden dynamics' within the global agrifood industry, especially in the context of South-North relations. The specific 'value' of such studies related to the crop sector can be further illustrated by addressing upgrading processes as a possible (and desirable) outcome of integrating local crop production into global distribution networks. Some critical reflections and 'unexpected' insights on these issues are compiled in the following considerations.

Firstly, the literature review has detected notable findings about the impact of trade on local crop production and consumption patterns that go beyond the global flows of foodstuffs per se. This argument mainly refers to (Gereffi and Christian 2010, p. 98) who state, "that most processed foods are created 'in-country' and connected to local food supply chains and production facilities and that the key role of imports and exports is to provide the ingredients that go into a wide array of food products." The authors illustrate these observations on the examples of soybeans in China and corn in Mexico. In both cases, trade liberalization and economic integration have had a tremendous impact on the agricultural system and domestic food supply. Thus, major changes in the trading of soybeans triggered by successive lowering of tariff rates after 2000 have clearly altered the food value chain in China. The result was a sharp increase of soybean imports as a response to rising demands for soybean-based oils and animal feed (Tuan et al. 2004). Furthermore, as imported soybeans are relatively cheap and contain high oil contents, they have become an attractive ingredient in the Chinese food culture. For example, soybean oils are used in pan frying, deep frying and baking, whereas soybean meal is fed to animals. Soybeans as an input commodity have also led to foreign direct investment in manufacturing, with Archer Daniels Midland (ADM), headquartered in Chicago, being the largest soybean processor in China by now. Simultaneously, Chinese firms have begun to adopt foreign food-processing practices, enabling them to upgrade into more profitable and powerful positions in the value chain (Gereffi and Christian 2010). The situation is similar in the Mexican case, where the North American Free Trade Agreement (NAFTA) has led to a rapid expansion of corn imports from the United States, particularly between 2003 and 2004. The imported corn is mostly a genetically modified US variety and there are indications that also genetically modified seeds are brought to Mexico for local farmers' use (Ross 2007). As a consequence, the flood of cheap US corn in the Mexican market has not only provoked tough competition in domestic corn cultivation resulting in multiple abandonments of farming operations but has also led to the cost-effective production of energy-dense foods (based on high fructose corn syrup) and thus indirectly to changes in food consumption patterns (Gereffi and Christian 2010). Hence, in both cases, it is revealed how changes in the institutional context affect the input-output structure and the geographic scope of two specific crop industries, resulting in the reconfiguration of crop value chains in both structural and organizational terms.

Secondly, crop value chain analyses may have the potential to assess the implications of economic and social up-/downgrading for producers and workers involved. We attribute this assertion to an extensive analysis of South African horticulture conducted by (Barrientos and Visser 2012). The importance of this study should be seen in the light of rapid changes in the fruit and vegetable sector that relate to the rise of domestic supermarket chains within South Africa. This trend has been opening up new distribution channels for producers who were until then strongly dependent on European retailers. The majority of South African fruit and vegetable growers appreciate that domestic supermarkets use procurement systems and apply standards along similar lines to their 
global counterparts but with more variability and less stringency. With the diversification of markets, horticulturalists could achieve better bargaining positions due to the availability of alternative options that are more accessible and thus easier to engage with. In response to this new competition, European retailers have begun to offer minimum price guarantees for the purchase of fruit from South Africa. Nevertheless, many weaker growers were pushed out of business, resulting in a more concentrated but ongoing fragile producer base (threatened by downgrading risk). (Barrientos and Visser 2012) further show that the pressures on economic up-/ downgrading have mixed outcomes in terms of social up-/downgrading for the labour force. On the one hand, the pressure to reduce labour costs and to be more flexible has fuelled increasing precariousness and casualization amongst the workforce. On the other hand, the proliferation of standards and the complexity of meeting diversified market requirements have driven a demand for more skilled workers with higher levels of education. Thus, economic upgrading in theory could support a process of social upgrading in South African horticulture. However, the pool of agricultural labour is traditionally poorly educated and farm work has clearly become less attractive to young people, also because of low salaries. Against this background, (Barrientos and Visser 2012, p. 38) critically conclude: "the sector faces a serious challenge if there is not a significant change in the skills and remuneration of workers. Public and private policy needs to provide more systematic support to social upgrading of workers through education, skills development and social provision to enhance the appeal and benefits of employment in agriculture."

Overall, the examples have shown that the uncovering of 'hidden dynamics' in global crop value chains requires an in-depth understanding of the institutional context dimension that strongly affects the production, distribution and consumption of crops and crop-based foods. To go even further, institutional settings in combination with world market developments are de facto considered as key drivers of crop systems transformation. Moreover and from an analytical viewpoint, it might be promising to explore the governance and power relations along crop value chains to further understand their transformational mechanisms at multiple scales. Some efforts in this direction have already been made by geographers such as, for example, (Challies and Murray 2011) who have analysed the insertion of the Chilean region Yerbas Buenas into the global raspberry market. The authors draw on the Global Value Chain (GVC) framework in combination with rural livelihoods approaches that have proven as useful to shed light on the construction of governance and the particular role played by institutions. In this case, the Ministry of Agriculture's development arm INDAP ${ }^{10}$ can be seen as a key mediating factor for the integration of smallholders into raspberry value chains that are driven to a great extent by large retailers from the Global North (for example, by setting the GlobalGAP standard).

\section{Discussion and Conclusions}

In this article, we have shown that the organization of crop value chains results from a number of interrelated phenomena occurring across different places and scales. More precisely, we could identify three strands of literature on global crop production and distribution systems: the integration of smallholders; the role of food standards; and the effect of 'hidden' dynamics. These issues especially reveal the interdependencies between the Global South and the Global North as a crucial feature of crop value chains in the current era of globalization.

The integration of smallholders into these value chains is often considered a promising strategy to improve rural livelihoods in developing countries. However, the literature on this issue is not consistent, as some authors emphasize the constraints of smallholders to participate in global value chains, while others stress the opportunities that are related with it. Besides the creation of enabling institutional frameworks, it is also important to enhance the capabilities of smallholders who sometimes develop their own strategies, as we have seen in the case of producer companies in India, presented by (Trebbin 2014). Another more radical opportunity refers to the renunciation from global crop value

10 Instituto de Desarrollo Agropecuario or Institute for Agricultural and Livestock Development. 
chains by (re-)focusing on local markets or mere subsistence economy, as suggested by (Baiphethi and Jacobs 2009).

The question whether or not smallholders are able to enter global crop value chains is closely linked to the role of food standards such as GlobalGAP set by large retailers from the Global North. Many authors have analysed the impact of these standards upon the upstream end of the value chain, with some of them arguing that small-scale producers from the Global South are often not able to meet the related requirements. As a result, they are excluded from the global crop market. However, there are also some authors who go beyond the 'exclusion debate,' while showing that smallholders nevertheless participate in buyer-driven crop value chains, even without being formally certified. This is possible due to various informal arrangements among farmers, brokers, exporters and other stakeholders, as shown by (Dannenberg and Nduru 2013) on the case of fruit and vegetable production in Kenya. By contrast, a third group of authors suggests alternative strategies for small crop producers to make themselves less dependent on the requirements of large retailing groups. These may include focusing on traditional domestic markets and/or niche products.

While analysing global crop value chains, several authors reveal (perhaps incidentally) the 'hidden dynamics' developing in the multiscalar relations between various stakeholders. For example, it has been shown that shifting institutional settings (e.g., trade liberalization) may not only affect transnational trade relations but even nutrition behaviours at country level, as in the cases of China (regarding soy-based foods) and Mexico (regarding corn-based foods). Moreover, the rise of domestic supermarkets in the Global South, such as in South Africa, has brought about a more diversified market for local crop producers with several outcomes-ranging from better bargaining positions with retailers from the Global North to higher requirements for education of the workforce to achieve upgrading (while, in practice, these requirements are difficult to meet).

All these issues can be seen as different types of challenges that clearly affect the manner of how crops are produced, distributed and consumed in the current era of globalization, while, simultaneously, shifting the nature and structure of South-North relations. For example, when small crop producers are able to develop smart strategies (e.g., making informal arrangements or entering alternative markets), they possibly appear no longer in a position of one-sided dependency vis-à-vis powerful actors from the Global North. In other cases, the one-sided dependency of smallholders may become even stronger, for example, when they fail in meeting the requirements set by downstream customers. Adopting a geographical perspective in the literature review allowed us to detect, at least in part, the complex interrelations and interdependencies that exist between developing and developed countries. Understanding these spatio-relational dimensions is, from our viewpoint, an important precondition for analysing the global crop sector and the specific geographical settings in which crop producers, distributors and buyers are embedded. The fact that 'geography matters' has become particularly obvious in studies dealing with rural livelihoods development and the impact of global forces (e.g., trade liberalization) on small-scale crop production. It is the way of how (traditional) local production and consumption patterns in the Global South are challenged and, to some extent, disembedded by confrontation with modern food systems which is of particular interest, not least from a developmental viewpoint. We argue that the variety of spatial patterns and multiscalar relations in contemporary food systems, that we have tried to exemplify on the global crop sector, might be explored most thoroughly through a multidisciplinary lens. From our viewpoint, geographers are predestined to play a key role in such efforts, due to their holistic approaches that may integrate economic, social and ecological issues. Thus, geographers may especially contribute to the formulation and implementation of sustainable development strategies with a particular focus on food security and rural livelihoods.

Even though the literature review has revealed a wide range of issues researched, there remain some areas of needed progress. Firstly, we found that most publications dealing with crop value chains are focused on South-North or South-South relations. Even though we recognize the importance of this work in the context of globalization, we nevertheless argue for a stronger consideration of 
North-North relations again. The ongoing processes of intensification, concentration and specialization that predominantly characterize the conventional agrifood sector in the Global North are still worthy of attention. While this long-lasting trajectory of 'productivism' is increasingly criticized due to various related problems (e.g., soil degradation, competition for land use, precarious employment), numerous voices calling for a food systems transformation are being raised (e.g., Food and Agriculture Organization of the United Nations FAO; Maye and Duncan 2017). In this light, there is still more research needed especially focusing on sustainability potentials within crop value chains in the Global North. Secondly, the literature reviewed has indicated that research activities almost always concentrate on the flowers and fruits of plants, with only limited attention to the roots, peels and stems. This observation is also confirmed by (Shukla and Jharkharia 2013). Thus, the by-products mentioned are mostly regarded as 'waste,' even though they may in fact provide several opportunities, not least in terms of value creation. This leads us to a research topic that is still underdeveloped from our viewpoint, that is, the closing of resource cycles. In order to use resources more sustainably, a promising strategy incorporates alternative utilizations of by-products normally accruing along crop value chains in manifold ways. By-products may include not only peels, stems, roots or other residues from crop production but also misshapen (though edible) crops that are not marketable for optical reasons. It is thus appreciable to encourage research activities aiming at the valorization of by-products, following the idea 'from cradle to cradle'. In order to find sustainable ways for making use of by-products and their innovative potentials, we consider interdisciplinary research as most promising, also for enriching scientific debates around food waste management or the emerging topic of 'food waste geography' (Evans 2011, 2014; Goodman 2016; Gregson and Crang 2010).

Beside the formulation of research needs, our paper contributes to the academic debate by synthesizing the existing literature on global crop value chains as a means of thematically 'organizing' and differentiating the key findings of relevant empirical studies. The global importance of crop value chains is undisputed due to their function for basic nutrition of billions of people, particularly in developing countries. At the same time, crop production is highly vulnerable due to various economic, political and environmental impacts. Against this background, we feel that time has come to provide an overview regarding the changing nature of crop value chains under the conditions of globalization. We acknowledge that our effort does not include a holistic synopsis of pertinent literature; it is rather a selective cross-section of articles and papers that directly or indirectly address the emergence of 'new geographies' in crop value chains at the nexus between the Global South and the Global North.

Author Contributions: Conceptualization, S.N., O.K. and C.T.; methodology, S.N.; validation, S.N., O.K. and C.T.; investigation and formal analysis, S.N.; writing-original draft preparation, S.N. and O.K.; writing-review and editing, O.K. and C.T.; supervision, C.T.; project administration, S.N.; funding acquisition, O.K. and C.T.

Funding: This research was funded by the Ministry of Science and Culture, Lower Saxony, Germany.

Conflicts of Interest: The authors declare no conflict of interest. The funders had no role in the design of the study; in the collection, analysis or interpretation of data; in the writing of the manuscript or in the decision to publish the results.

\section{References}

Alkon, Alison, and Julie Guthman, eds. 2017. The New Food Activism. Opposition, Cooperation and Collective Action. Oakland: University of California Press.

Båge, Lennart. 2008. Supporting Smallholders is Crucial to Food Security. As Published in the G8 Summit Special Report of the Financial Times, July 7. Available online: https: / /www.ifad.org/web/latest/speech/asset/ 39036847 (accessed on 8 November 2018).

Baiphethi, Mompati N., and Peter T. Jacobs. 2009. The Contribution of Subsistence Farming to Food Security in South Africa. Agrekon 48: 1-27. [CrossRef]

Barrientos, Stephanie, and Catherine Dolan. 2006. Ethical Sourcing in the Global Food System. London: Routledge. 
Barrientos, Stephanie, and Margareet Visser. 2012. South African Horticulture: Opportunities and Challenges for Economic and Social Upgrading in Value chains. Capturing the Gains Working Paper 2012/12. School of Environment and Development, University of Manchester. Available online: https:/ / papers.ssm.com/sol3/ papers.cfm (accessed on 25 October 2018).

Bek, David, Tony Binns, Thijs Blokker, Cheryl McEwan, and Alexandra Hughes. 2016. A High Road to Sustainability? Wildflower Harvesting, Ethical Trade and Social Upgrading in South Africa's Western Cape. Journal of Agrarian Change 17: 459-79. [CrossRef]

Bolwig, Simon, Lone Riisgard, Peter Gibbon, and Stefano Ponte. 2013. Challenges of Agro-food Standards Conformity: Lessons From East Africa and Policy Implications. European Journal of Development Research 25: 408-27. [CrossRef]

Bonnano, Alessandro, Carlo Russo, and Luisa Menapace. 2018. Market Power and Bargaining in Agrifood Markets: A Review of Emerging Topics and Tools. Agribusiness 34: 6-23. [CrossRef]

Brown, Oli. 2005. Supermarket Buying Power, Global Commoditiy Chains, and Smallholder Farmers in the Developing World. Human Development Report Office, Occasional Paper 2005/4. Available online: http: //hdr.undp.org/sites/default/files/hdr2005_brown_oli_41.pdf (accessed on 26 November 2018).

Challies, Edward R. T., and Warwick E. Murray. 2011. The Interaction of Global Value Chains and Rural Livelihoods: The Case of Smallholder Raspberry Growers in Chile. Journal of Agrarian Change 11: 29-59. [CrossRef]

Dannenberg, Peter, and Gilbert Nduru. 2013. Practices in International Value Chains: The Case of the Kenyan Fruit and Vegetable Chain Beyond the Exclusion Debate. Tijdschrift voor Economische en Sociale Geografie 104: 41-56. [CrossRef]

Dobson, Paul W., Michael Waterson, and Stephen W. Davies. 2003. The Patterns and Implications of Increasing Concentration in European Food Retailing. Journal of Agricultural Economics 54: 111-25. [CrossRef]

Evans, Daniel. 2011. Thrifty, Green or Frugal: Reflections on Sustainable Consumption in a Changing Economic Climate. Geoforum 42: 550-57. [CrossRef]

Evans, Daniel. 2014. Food Waste: Home Consumption, Material Culture and Everyday Life. London: Bloomsbury.

Food and Agriculture Organization of the United Nations (FAO). 2010. World Programme for the Census of Agriculture 2010. Appendix 3: Classification of Crops. Rome. Available online: http://www.fao. org/fileadmin/templates/ess/documents/world_census_of_agriculture/appendix3_r7.pdf (accessed on 18 February 2019).

Food and Agriculture Organization of the United Nations (FAO). 2013. Transformation of Food Systems Needed for Better Nutrition. Rome. Available online: http:/ / www.fao.org/news/story/en/item/204232/icode/ (accessed on 26 October 2018).

Food and Agriculture Organization of the United Nations (FAO). 2017. The Future of Food and Agriculture. Trends and Challenges. Rome. Available online: http:/ / www.fao.org/3/a-i6583e.pdf (accessed on 2 October 2018).

Fold, Niels, and Katherine Gough. 2008. From Smallholders to Transnationals: The Impact of Changing Consumer Preferences in the EU on Ghana's Pineapple Sector. Geoforum 39: 1687-97. [CrossRef]

Fold, Niels, and Marianne N. Larsen. 2011. Upgrading of Smallholder Agro-food Production in Africa: The Role of Lead Firm Strategies and New Markets. International Journal of Technological Learning, Innovation and Development 4: 39-66. [CrossRef]

Fraser, Alistair. 2016. Global Foodscapes. In Oppression and Resistance in the Life of Food. London: Routledge.

Gaiha, Raghav, and Ganesh Thapa. 2008. Supermarkets, Smallholders and Livelihoods Prospects in Selected Asian Countries. In The Indian Economy Sixty Years After Independence. Edited by Raghbendra Jha. London: Palgrave McMillan, pp. 247-62.

Gereffi, Gary, and Michelle M. Christian. 2010. Trade, Transnational Corporations and Food Consumption: A Global Value Chain Approach. In Trade, Food, Diet and Health: Perspectives and Policy Options. Edited by Corinna Hawkes, Chantal Blouin, Henson Spencer, Nick Drager and Laurette Dubé. Oxford: Wiley-Blackwell, pp. 91-110.

Gijsbers, Govert W. 2009. Agricultural Innovation in Asia. Drivers, Paradigms and Performance. Ph.D. Thesis, Erasmus Universiteit Rotterdam, Rotterdam, The Netherlands. 
Gooch, Martin, Abdel Felfel, and Nicole Marenick. 2010. Food Waste in Canada. Opportunities to Increase the Competitiveness of Canada's Agri-food Sector, While Simultaneously Improving the Environment. Oakville: Value Chain Mangement Centre, Available online: http:/ /vcm-international.com/wp-content/uploads/2013/04/ Food-Waste-in-Canada-112410.pdf (accessed on 26 October 2018).

Goodman, Michael K. 2016. Relational Foodscapes and the Busy-ness of Being More-than-food. Progress in Human Geography 40: 257-66. [CrossRef]

Goodman, Michael K., Damian Maye, and Lewis Holloway. 2010. Ethical Foodscapes? Premises, Promises and Possibillities. Environment and Planning 42: 1782-96. [CrossRef]

Graffham, Andy, Ester Karehu, and James MacGregor. 2007. Impact of EurepGAP on Small-Scale Vegetable Growers in Kenya. London: International Institute for Environment and Development.

Gregson, Nicky, and Mike Crang. 2010. Materiality and Waste: Inorganic Vitality in a Networked World. Environment and Planning 42: 1026-32. [CrossRef]

Hawkes, Corinna, and Marie T. Ruel. 2012. Value Chains for Nutrition. In Reshaping Agriculture for Nutrition and Health. Edited by Shenggen Fan and Rahul Pandya-Lorch. Washington: IFPRI, pp. 73-81.

Howard, Philip H. 2016. Concentration and Power in the Food System. Who Controls What We Eat? London: Bloomsbury Academic.

Hughes, Alexandra, Cheryl McEwan, and David Bek. 2013. Retailers, Supply Networks and Changing Articulations of Ethicality: Lessons from Flower Valley in South Africa. Journal of Economic Geography 13: 211-30. [CrossRef]

Humphrey, John. 2006a. Policy Implications of Trends in Agribusiness Value Chains. The European Journal of Development Research 18: 572-92. [CrossRef]

Humphrey, John. 2006b. Horticulture: Responding to the Challenges of Poverty Reduction and Global Competition. In I International Symposium on Improving the Performance of Supply Chains in the Transitional Economies. Edited by Peter J. Batt. Chiang Mai: ISHS, pp. 19-41.

Humphrey, John. 2008. Private Standards, Small Farmers and Donor Policy: EUREPGAP in Kenya. IDS Working Papers 308. Brighton. Available online: https:/ / opendocs.ids.ac.uk/opendocs/bitstream/handle/ 123456789/4167 /Wp308.pdf?sequence=1\&isAllowed=y (accessed on 27 November 2018).

Humphrey, John, and Olga Memedovic. 2006. Global Value Chains in the Agrifood Sector. UNIDO Working Papers. Vienna. Available online: https://www.unido.org/sites/default/files/2009--05/Global_value_ chains_in_the_agrifood_sector_0.pdf (accessed on 27 November 2018).

Ito, Junichi, Zongshun Bao, and Qun Su. 2012. Distributional Effects of Agricultural Cooperatives in China: Exclusion of Smallholders and Potential Gains on Participation. Food Policy 37: 700-09. [CrossRef]

Jack, B. Kelsey. 2013. Market Inefficiencies and the Adoption of Agricultural Technologies in Developing Countries. CEGA White Papers. Berkele: University of California, Available online: https:/ / escholarship.org/uc/item/ $6 \mathrm{~m} 25 \mathrm{r} 19 \mathrm{c}$ (accessed on 29 November 2018).

Jaenicke, Hannah, and Detlef Virchow. 2013. Entry Points into a Nutrition-sensitive Agriculture. Food Security 5: 679-92. [CrossRef]

Jayne, Thomas S., Antony Chapoto, and Jones Govereh. 2010. Grain Marketing Policy at the Crossroads: Challenges for Eastern and Southern Africa. In Food Security in Africa. Market and Trade Policy for Staple Foods in Eastern and Southern Africa. Edited by Alexander Sarris and Jamie Morrison. Cheltenham: Edward Elgar, pp. 115-57.

López-Fernández, Ma C., Ana M. Serrano-Bedia, and Marta Pérez-Pérez. 2016. Entrepreneurship and Family Firm Research: A Bibliometric Analysis of an Emerging Field. Journal of Small Business Management 54: 622-39. [CrossRef]

Maye, Damian, and Jessica Duncan. 2017. Understanding Sustainable Food System Transitions. Practice, Assessment and Governance. Sociologia Ruralis 57: 267-73. [CrossRef]

Mayring, Philipp. 2014. Qualitative Content Analysis: Theoretical Foundation, Basic Procedures and Software Solution. Klagenfurt: SSOAR, Available online: https://www.ssoar.info/ssoar/handle/document/39517 (accessed on 8 November 2018).

McCulloch, Neil, and Masako Ota. 2002. Export Horticulture and Poverty in Kenya. IDS Working Papers 174. Brighton. Available online: https:/ / www.ids.ac.uk/files/Wp174.pdf (accessed on 29 November 2018).

Miller, Dennis D., and Ross M. Welch. 2013. Food System Strategies for Preventing Micronutrient Malnutrition. Food Policy 42: 115-28. [CrossRef] 
Mithöfer, Dagmar, Eddah Nang'ole, and Solomon Asfaw. 2008. Smallholder Access to the Export Market: The Case of Vegetables in Kenya. Outlook on Agriculture 37: 203-11. [CrossRef]

Monteiro, Carlos A., Jean-Claude Moubarac, Geoffrey Cannon, Shu W. Ng, and Barry M. Popkin. 2013. Ultra-processed Products are Becoming Dominant in the Global Food System. Obesity Reviews 14: 21-28. [CrossRef] [PubMed]

Morgan, Kevin, Terry Marsden, and Jonathan Murdoch. 2006. Worlds of Food. Place, Power and Provenance in the Food Chain. Oxford: Oxford University Press.

Niles, Daniel, and Robin Jane Roff. 2008. Shifting Agrifood Systems: The Contemporary Geography of Food and Agriculture; an Introduction. GeoJournal 73: 1-10. [CrossRef]

Ponte, Stefano. 2016. Convention Theory in the Anglophone Agro-food Literature: Past, Present and Future. Journal of Rural Studies 44: 12-23. [CrossRef]

Pritchard, Bill, Jane Dixon, Elizabeth Hull, and Chetan Choithani. 2016. 'Stepping Back and Moving in': The Role of the State in the Contemporary Food Regime. Journal of Peasant Studies 43: 693-710. [CrossRef]

Reardon, Thomas, and Julio A. Berdegué. 2002. The rapid rise of supermarkets in Latin America: challenges and opportunities for development. Development Policy Review 20: 371-388. [CrossRef]

Reardon, Thomas, and C. Peter Timmer. 2012. The Economics of the Food System Revolution. Annual Review of Resource Economics 4: 225-64. [CrossRef]

Reardon, Thomas, C. Peter Timmer, Christopher B. Barrett, and Julio A. Berdegué. 2003. The Rise of Supermarkets in Africa, Asia and Latin America. American Journal of Agricultural Economics 85: 1140-46. [CrossRef]

Reardon, Thomas, Spencer Henson, and Julio A. Berdegué. 2007. 'Proactive fast-tracking' diffusion of supermarkets in developing countries: implications for market institutions and trade. Journal of Economic Geography 7: 399-431. [CrossRef]

Riisgaard, Lone, Simon Bolwig, Frank Matose, Stefano Ponte, Andries Du Toit, and Niels Halberg. 2008. A Strategic Framework and Toolbox for Action Research with Small Producers in Value Chains. DIIS Working Papers 2008/17. Copenhagen. Available online: https://www.diis.dk/files/media/documents/ publications/wp08--17_strategic_framework_and_toolbox_for_action_research_with_small_producers_ in_value-chains.pdf (accessed on 8 November 2018).

Riisgaard, Lone, Simon Bolwig, Stefano Ponte, Andries Du Toit, Niels Halberg, and Frank Matose. 2010. Integrating Poverty and Environmental Concerns into Value-chain Analysis: A Strategic Framework and Practical Guide. Development Policy Review 28: 195-216. [CrossRef]

Ross, John. 2007. The Last Days of Mexican Corn. Counter Punch. November 21. Available online: https: / / www.counterpunch.org/2007/11/21/the-last-days-of-mexican-corn/ (accessed on 30 November 2018).

Ruel, Marie T., Harold Alderman, and Maternal and Child Nutrition Study Group. 2014. Nutrition-sensitive Interventions and Programmes: How Can They Help to Accelerate Progress in Improving Maternal and Child Nutrition? In Food Security 4: Food Policy for Food Security. Edited by Mark W. Rosegrant. Thousand Oaks: SAGE Publications Ltd., Available online: http:/ /www.ifpri.org/publication/nutrition-sensitiveinterventions-and-programmes (accessed on 30 November 2018).

Schneider, Kate, and Mary Kay Gugerty. 2011. Agricultural Productivity and Poverty Reduction: Linkages and Pathways. Evans School Review 1: 56-74. [CrossRef]

Schröder, Monika J. A. 2003. Food Quality and Consumer Value. Delivering Food That Satisfies. Heidelberg: Springer. Schumacher, Kim Philip. 2014. Gender Relations in Global Agri-food Value Chains-A Review. Die Erde 145: 127-34.

Seville, Don, Abbi Buxton, and Bill Vorley. 2011. Under What Conditions Are Value Chains Effective Tools for Pro-poor Development? Report for the Ford Foundation. Vermont: Sustainable Food Laboratory, Available online: http:/ / pqpublications.squarespace.com/publications/2013/1/16/under-what-conditionsare-value-chains-effective-tools-for-p.html (accessed on 30 November 2018).

Shukla, Manish, and Sanjay Jharkharia. 2013. Agri-fresh Produce Supply Chain Management: A State-of-the-art Literature Review. International Journal of Operations and Production Management 33: 114-58. [CrossRef]

Spaargaren, Gert, Peter Oosterveer, and Anne Loeber. 2012. Sustainability Transitions in Food Con-sumption, Retail and Production. In Food Practices in Transition. Changing Food Consumption, Retail and Production in the Age of Reflexive Modernity. Edited by Geert Spargaaren, Peter Oosterveer and Anne Loeber. London: Routledge, pp. 1-32. 
Stringer, Christina, and Richard B. Le Heron, eds. 2008. Agri-food Commodity Chains and Globalising Networks. Aldershot: Ashgate.

Swinnen, Johan F. M., ed. 2007. Global Supply Chains, Standards and the Poor. How the Globalization of Food Systems and Standards Affects Rural Development and Poverty. Wallingford: CABI.

Tamásy, Christine. 2013. Areas of Intensive Livestock Agriculture as Emerging Alternative Economic Spaces? Applied Geography 45: 385-91. [CrossRef]

Thomsen, Lotte. 2016. Exporting to Russia? Entry Barriers for Food Suppliers in a Territory in Transition. Journal of Economic Geography 16: 831-47. [CrossRef]

Trebbin, Anika. 2014. Linking Small Farmers to Modern Retail Through Producer Organizations-Experiences with Producer Companies in India. Food Policy 45: 35-44. [CrossRef]

Tuan, Francis C., Cheng Fang, and Zhi Cao. 2004. China's Soybean Imports Expected to Grow Despite Short-Term Disruptions; Beltsville: Economic Research Service USDA. Available online: https:/ /naldc.nal.usda.gov / download/34165/PDF (accessed on 30 November 2018).

Vorley, Bill, Andrew Fearne, and Derek Ray, eds. 2007. Regoverning Markets. A Place for Small-Scale Producers in Modern Agrifood Chains? New York: Routledge.

Winter, Michael. 2003. Embeddedness, the New Food Economy and Defensive Localism. Journal of Rural Studies 19: 23-32. [CrossRef]

Winter, Michael. 2004. Geographies of Food: Agro-food Geographies-Farming, Food and Politics. Progress in Human Geography 28: 664-70. [CrossRef]

Winter, Michael. 2005. Geographies of Food: Agro-food Geographies-Food, Nature, Farmers and Agency. Progress in Human Geography 29: 609-17. [CrossRef]

Zientek, Linda R., Jon M. Werner, Mariela V. Campuzano, and Kim Nimon. 2018. Writer's Forum-The Use of Google Scholar for Research and Research Dissemination. New Horizons in Adult Education E Human Resource Development 30: 39-46.

(C) 2019 by the authors. Licensee MDPI, Basel, Switzerland. This article is an open access article distributed under the terms and conditions of the Creative Commons Attribution (CC BY) license (http:/ / creativecommons.org/licenses/by/4.0/). 